\title{
PENERAPAN MEDIA AUDIO VISUALUNTUK MENINGKATKAN AKTIVITAS DAN HASIL BELAJAR GAMBAR KONSTRUKSI BANGUNAN SMK NEGERI 1 PERCUT SEI TUAN TAHUN AJARAN 2016/2017
}

\author{
Aldini ${ }^{1}$, Nono Sebayang ${ }^{2}$ \\ ${ }^{1}$ Alumni Program Studi Pendidikan Teknik Bangunan, Fakultas Teknik UNIMED \\ ${ }^{2}$ Dosen Pengajar Jurusan Pendidikan Teknik Bangunan, Fakultas Teknik UNIMED \\ (sby_nono@yahoo.co.id)
}

\author{
Diterima $\quad$ : 10 Januari 2017 \\ Disetujui : : 14 Februari 2017
}

\begin{abstract}
ABSTRAK
Penelitian ini bertujuan untuk mengetahui peningkatan aktivitas dan hasil belajar siswa pada mata pelajaran gambar konstruksi bangunan melalui penerapan media audio visualpada siswa kelas XI Program keahlian Teknik Gambar Bangunan SMK Negeri 1 Percut Sei Tuan semester genap Tahun Ajaran 2016/2017. Rancangan penelitian yang digunakan adalah penelitian tindakan kelas (PTK). Hasil penelitian menunjukkan aktivitas belajar siswa meningkat, pada siklus I nilai rata-rata komulatif aktivitas siswa siklus I yaitu 75 dengan capaian 26,92\% siswa tidak aktif dengan nilai $<75$ dan 73,08\% siswa aktif dengan nilai $\geq 75$. Pada hasil nilai rata-rata aktivitas siswa siklus II yaitu mencapai 85 dengan capaian $100 \%$ siswa aktif dengan nilai $\geq 75$. Nilai hasil belajar siswa mengalami peningkatan, yaitu pada siklus I rata-rata hasil belajar siswa 76,91 dengan presentase ketuntasan siswa mencapai $73,08 \%$, dengan capaian target $26,92 \%$ nilai $<75$ dan $73,08 \%$ nilai $\geq 75$. Pada siklus II mengalami peningkatan nilai rata-rata hasil belajar siswa mencapai 85,08 dengan presentase ketuntasan siswa mencapai $100 \%$ atau 26 siswa dengan keterangan "Tuntas" yang mendapat nilai $\geq 75$. Dengan demikian, dapat disimpulkan bahwa penerapan media audio visual untuk meningkatkan Aktivitas dan Hasil Belajar Gambar Konstruksi Bangunan Pada Siswa Kelas XI Program Keahlian Teknik Gambar Bangunan SMK Negeri 1 Percut Sei Tuan Tahun Ajaran 2016/2017 membuktikan peningkatan hasil belajar dan aktivitas belajar siswa.
\end{abstract}

Kata Kunci : Aktivitas, Hasil Belajar, Media Audio Visual

\begin{abstract}
This research aims to know the increase in activity and results of student learning in the subjects building construction drawing through the application of audio visual media on the grade XI Engineering Program Image of the building at SMK Negeri 1 Percut Sei Tuan even semester academic year 2016/2017. The research design used was class action research (PTK). Research results drawn from the test results of student learning and the observation sheet. The study is said to be successfully measured by average komulatif activity and the results of learning students acquire a minimum 75 and finished in classical if the whole class $\geq 75 \%$ of its students has been completed. The results showed increased student learning activities, in cycle I, the average value of komulatif student activity cycle I i.e. 75 with close $26.92 \%$ of students not actively 73.08 and $75 \%<$ students active $\geq 75$. On the results of the average value of the student's activity cycle II IE achieve 85 with close to $100 \%$ active $\geq 75$ students. Student learning outcomes and value increase in cycle I, the average student
\end{abstract}


learning 76.91 results with the percentage of the ketuntasan students reached $73,08 \%$, close to the target of 75 per cent $<26.92$ and $73.08 \%$ value of $\geq 75$. And in cycle II experienced an increase in the average value of student learning outcomes achieved with 85.08 ketuntasan percentage of students achieving $100 \%$ or 26 students with the description "Complete" that gets a value $\geq 75$. Thus, it can be concluded that the application of audio visual media to enhance the activity and results of the Study On building construction Drawing Students of Class XI Engineering Program Image of the building a SMK Negeri 1 Percut Sei Tuan school year 2016/2017 proves an increased yield learning and learning activities of students.

Keywords: Activities, Audio Visual Media, Learning Outcomes

\section{Pendahuluan}

Pendidikan merupakan kebutuhan yang mendasar yang harus dimiliki oleh manusia, karena tanpa pendidikan manusia tidak akan bisa meningkatkan taraf hidupnya. Dengan pendidikan diharapkan manusia akan lebih mampu untuk mengembangkan dirinya. Masalah pendidikan adalah masalah yang sangat penting bagi manusia, karena pendidikan tersebut menyangkut kelangsungan hidup manusia. Menyadari akan hal tersebut, pemerintah sangat serius menangani bidang pendidikan, sebab dengan sistem pendidikan yang baik diharapkan muncul generasi penerus bangsa yang berkualitas dan mampu menyesuaikan diri untuk hidup bermasyarakat, berbangsa dan bernegara.

SMK Negeri 1 Percut Sei Tuan adalah salah satu SMK yang memberikan bekal pengetahuan, teknologi, keterampilan, disiplin, dan sikap etos kerja yang kuat dan terampil dalam bidangnya sehingga diharapkan dapat bersaing di industri kerja. SMK ini memiliki Program Kejuruan yaitu Teknik Otomotif, Teknik Permesinan, Teknik Bangunan, Teknik Audio-video, Teknik Listrik, Teknik Komputer Jaringan dan Teknik Pendingin dan Tata Udara. Dari berbagai Program Kejuruan yang ada salah satu Program Studi Keahlian yang dimiliki SMK ini adalah Program Keahlian Teknik Gambar Bangunan, dimana mempersiapkan siswa agar dapat bersaing dan memenuhi kebutuhan lapangan kerja.

Pada Program Keahlian Teknik Gambar Bangunan ada tiga jenis mata pelajaran yang digolongkan yakni: Mata Pelajaran Normatif, Adaptif, dan Produktif. Dari ketiga golongan mata pelajaran ini, Mata Pelajaran Produktif merupakan salah satu mata pelajaran yang sangat penting, karena siswa dituntut untuk mempunyai pengetahuan, keterampilan, dan kemampuan yang merupakan bekal bagi para siswa nantinya untuk dapat diterapkan dan dikembangkan pada dunia kerja. Salah satu mata pelajaran yang termasuk dalam mata pelajaran produktif tersebut adalah Gambar Konstruksi Bangunan. Pada mata pelajaran gambar konstruksi bangunan peserta didik diharapkan memiliki keahlian dan keterampilan dalam menggambar konstruksi bangunan baik secara manual ataupun menggunakan perangkat lunak seperti autocad.

Salah satu media pembelajaran yang dianggap tepat untuk dapat meningkatkan aktivitas dan hasil belajar siswa adalah media audio visual. Adapun perbedaan antara media visual (lembar jobsheet) dengan media audio visual yang dilakukan guru di dalam proses belajar mengajar. Dimana kreasi, bentuk, warna dan gambar yang dihasilkan tidak begitu menarik dan gambar yang dihasilkan tidak begitu akurat dan didalam melaksanakan proses belajar mengajar waktu yang dibutukan terbuang banyak untuk menjelaskan dan menggambarkan di papan tulis sehingga gurulah yang lebih aktif dalam pembelajaran. Sedangkan media audio visual mempunyai pemprograman yang begitu mudah dan didalamnya dapat menggabungkan unsurunsur media lainnya.

Cara mengajar dengan menggunakan media audio visual merupakan suatu cara mengajar yang digunakan untuk menyampaikan informasi atau uraian tentang satu pokok persoalan. Media audio visual semakin lama semakin populer dimasyarakat kita. Pesan yang disajikan dapat bersifat fakta (kejadian, berita yang bersifat penting) maupun fiktif (bentuk cerita) bisa berbentuk informasi, edukatif, maupun intruksional. Pengunaan media audio visual selain mudah, waktu yang 
dibutuhkan dalam menampilkan dan menjelaskan pembelajaran cukup efesien. Dengan lebih sedikitnya waktu yang dibutuhkan oleh guru untuk menyampaikan materi pembelajaran dalam arti materi yang diterangkan cukup lengkap maka guru dan siswa akan lebih banyak waktu untuk tanya jawab, sehingga siswa akan lebih berperan aktif dalam mengikuti pelajaran.

Berdasarkan uraian di atas, maka penulis tertarik untuk melakukan penelitian dengan judul "Penerapan Media Audio Visual untuk Meningkatkan Aktivitas dan Hasil Belajar Gambar Konstruksi Bangunan Siswa Kelas XI Program Keahlian Teknik Gambar Bangunan SMK Negeri 1 Percut Sei Tuan Tahun Ajaran 2016/2017".

\section{Kajian Teori}

Belajar adalah suatu upaya yang dilakukan seseorang untuk mendapatkan perubahan tingkah laku akibat interaksi individu dengan lingkungannya baik tentang pengetahuan, sikap dan keterampilan sedangkan hasil belajar merupakan tolak ukur yang digunakan untuk mengetahui tingkat keberhasilan siswa dalam mencapai tujuan pembelajaran. Sejauh mana siswa mengetahui dan memahami materi pelajaran yang disampaikan guru biasanya hasil belajar dinyatakan dengan nilai berupa angka dan huruf. Hasil belajar berupa bagaimana pengetahuan, keterampilan, dan sikap siswa setelah mengalami proses belajar.

Gambar Konstruksi adalah gambar yang memuat informasi-informasi teknis suatu bangunan dengan lebih mendetail, seperti material yang dipakai, konstruksi sambungan, posisi kolom balok, plumbing (perpipaan), kelistrikan, dan sebagainya.Gambar seperti ini dipakai sebagai pedoman pelaksanaan pembangunan di lapangan.Karena fungsinya demikian, tidak seperti halnya gambar presentasi yang memang mengedepankan keindahan, gambar teknik sangat menekankan ketepatan dan kelengkapan gambar. Semakin rumit wujud dan fungsi bangunan, maka akan semakin banyak gambar yang dibutuhkan sehingga memudahkan dalam pelaksanaan konstruksi nantinya.

Maka dapat disimpulkan gambar konstruksi bangunan adalah gambar yang digunakan sebagai alat komunikasi yang memberikan ilustrasi tentang bangunan.Selain untuk menampilkan wujud fisik bangunannya, gambar-gambar ini digunakan sebagai bahan pertimbangan dalam merencanakan struktur bangunan dan sistem utilitas di dalamnya sehingga selain bangunan tersebut terlihat indah, juga aman dan nyaman untuk ditempati.

Gambar Konstruksi Bangunan sebagai salah satu mata pelajaran dalam kompetensi keahlian teknik bangunan yang tentunya memiliki tujuan pembelajaran yang harus dicapai sesuai dengan silabus yang digunakan. Berkenaan dengan materi yang dipelajari dalam gambar konstruksi bangunan yang mengacu pada silabus semester IV (genap), siswa akan mempelajari berbagai kompetensi dasar, yaitu :menggambar konstruksi beton bertulang, spesifikasi dan ketentuan teknis pada gambar tangga, menggambar kontruksi atap dan langit-langit, dan mengambar utilitas bangunan gedung.Dari semua kompetensi dasar dalam mata pelajaran Gambar konstruksi bangunan semester genap, yang peneliti jadikan bahan penelitian adalah kompetensi dasar spesifikasi dan ketentuan teknis pada gambar tangga dengan materi pokok menggambar konstruksi tangga.

Berdasarkan uraian diatas maka dapat disimpulkan bahwa hasil belajar gambar konstruksi bangunan adalah suatu akibat dari proses pembelajaran menggambar secara manual dengan mencapai tujuan pengajaran yang diwujudkan dengan nilai.

Pengertian media pembelajaran Audio visual menurut Munadi (2008:56) adalah media yang melibatkan indera pendengaran dan pengelihatan sekaligus dalam satu proses. Sifat pesan yang disalurkan melalui media dapat berupa pesan verbal dan non verbal yang terlihat layaknya media visual juga pesan verbal dan non verbal yang terdengar layaknya media audio. Pesan visual yang terdengar dan terlihat itu dapat disajikan melalui program Audio visual seperti film dokumenter, film drama, dan lain-lain. Semua program tersebut dapat disalurkan melalui peralatan seperti video dan juga televisi dan dapat disambungkan pada alat proyeksi (projactable aids).Kemampuan media ini dianggap lebih baik dan lebih menarik, sebab mengandung kedua jenis media baik adiptif dan juga visual. Penggunaan audio visual sangat efektif dilakukan dalam hal pemanfaatan alat inderanya adalah yang terbanyak di dalam setiap kelas. Artinya siswa dapat dan mampu mengikuti pelajaran dengan menggunakan 
lebih dari satu alat inderanya, yaitu indera pendengaran dan indera penglihatan.

Media audio visual pada pola penyajiannya digunakan sebagai alat bantu bagi guru untuk menyampaikan materi dan kontrol pembelajaran terletak pada guru. Pada saat pelaksanaan tindakan, peneliti dapat melihat hasil observasi (pengamatan) untuk mengetahui aktivitas belajar siswa. Adapun aspek yang dinilai oleh peneliti pada saat melakukan observasi yaitu: 1). Antusias dalam KBM (memperhatikan); 2). Mengajukan pertanyaan; 3). Menggambar; 4). Menanggapi pertanyaan; 5). Mengeluarkan pendapat. Dari penjelasan di atas dapat diduga bahwa melalui Penerapan Media Pembelajaran Audio Visual dapat meningkatkan aktivitas siswa dalam belajar Gambar Konstruksi Bangunan.

\section{Metodologi Penelitian}

Penelitian tindakan kelas akan dilaksanakan di SMK Negeri 1 Percut Sei TuanTahun Ajaran 2016/2017 Program Keahlian Teknik Gambar Bangunan pada mata pelajaran Gambar Konstruksi Bangunan. Penelitian ini dilaksanakan pada kelas XI TGB 2 semester genap bulan Februari sampai selesai

Pada penelitian ini yang menjadi subjek penelitian adalah siswa kelas XI Program Keahlian Teknik Gambar Bangunan (XI TGB 2) di SMK Negeri 1 Percut Sei Tuan dengan jumlah sebanyak 26 siswa. Objek penelitian ini adalah Penerapan media audio visual (video) untuk meningkatkan aktivitas dan hasil belajar mata pelajaran gambar konstruksi bangunan pada Kompetensi Dasar Spesifikasi dan Ketentuan Teknis pada Gambar Tangga dengan materi pokok menggambar tangga di kelas XI Program Keahlian Teknik Gambar Bangunan SMK Negeri 1 Percut Sei Tuan T.P. 2016/2017.

Partisipan dalam penelitian ini adalah siswa kelas XI Program Keahlian Teknik Gambar Bangunan (XI TGB 2) SMK Negeri 1 Percut Sei Tuan dalam penelitian ini dilaksanakan oleh satu orang guru mata pelajaran Gambar Konstruksi Bangunan pada Kompetensi Dasar Spesifikasi dan Ketentuan Teknis pada Gambar Tangga dengan materi pokok menggambar konstruksi tangga sebagai pelaku tindakan dan peneliti sendiri sebagai observer serta bermitra dengan pihak lain, seperti teman sejawat mahasiswa dalam melaksanakan tindakan penelitian di kelas.
Adapun defenisi operasional dalam penelitian ini adalah sebagai berikut:

a. Hasil Belajar Gambar Konstruksi Bangunan adalah angka atau skor yang diperoleh melalui proses belajar mengajar yang menunjukan penguasaan ranah afektif, kognitif dan psikomotor siswa terhadap mata pelajaran Gambar Konstruksi Bangunan Kompetensi Dasar Spesifikasi dan Ketentuan Teknis pada Gambar Tangga dengan materi pokok menggambar konstruksi tangga. Untuk mengetahui ranah afektif, teknik pengumpulan data menggunakan penilaian diri dan alat pengumpulan data menggunakan lembar pernyataan disetiap aspek sikap sosial yang akan diteliti (disiplin dan tanggung jawab) yang disesuaikan dengan indikator. Untuk ranah kognitif, teknik pengumpulan data menggunakan tes tertulis post test pilihan berganda. Untuk ranah psikomotor, teknik pengumpulan data menggunakan tes praktek yaitu menggambar.

b. Aktivitas Belajar siswa adalah hasil observasi tingkah laku belajar siswa dalam proses belajar Gambar Konstruksi Bangunan, dimana indikator pencapaian untuk mengetahui tingkat keaktifan siswa yaitu : 1) memperhatikan pelajaran, 2) mengajukan pertanyaan, 3) mengeluarkan pendapat, 4) menggambar, 5) tenang. Teknik pengumpulan data menggunakan observasi/pengamatan dan alat pengumpulan data menggunakan lembar pengamatan/observasi untuk mengetahui aktivitas belajar siswa

c. Media pembelajaran audio visual adalah penggunaan media (video berbentuk film bingkai suara) sebagai alat bantu yang digunakan oleh guru untuk menyalurkan pesan (bahan pembelajaran) kepada siswa dalam proses pembelajaran, dimana dalam proses pelaksanaan belajar mengajar tersebut guru menggunakan media pembelajaran berbentuk video karena diharapkan dapat merangsang daya kognitif, afektif dan psikomotorik siswa, yang dirancang oleh peneliti sesuai dengan kompetensi dasar dan kebutuhan belajar mengajar dikelas

Penelitian tindakan kelas ini, keputusan untuk melanjutkan atau menghentikan penelitian bergantung pada setiap akhir siklus penelitian, baik pada siklus I maupun siklus II.Hasil belajar siswa dianalisis dengan melihat 
ketuntasan belajar siswa.Berdasarkan Standart Ketuntasan Belajar Minimal (SKBM) yang ditetapkan dalam kompetensi dasar pada penelitian tindakan ini, maka seorang siswa telah dikatakan mencapai kompetensi jika siswa memperoleh skor 75 atau 3,00 dan tuntas secara klasikal jika seluruh kelas $\geq 75 \%$ diantara siswanya sudah tuntas belajar.

\section{Hasil dan Pembahasan}

Indikator keberhasilan Penerapan Media Audio Visual untuk Meningkatkan Aktivitas dan Hasil Belajar Gambar Konstruksi Bangunan Siswa Kelas XI Program Keahlian Teknik Gambar Bangunan SMK Negeri 1 Percut Sei Tuan adalah sebagai berikut :

\section{a. Aktivitas Belajar}

* Rata-rata nilai aktivitas siswa sesuai KKM minimal nilai 75dengan ketercapaian sekurang-kurangnya $75 \%$ (ketuntasan klasikal) mengacu pada kriteria ketuntasan belajar minimum yang diterapkan SMK Negeri 1 Percut Sei Tuan.

* Sesuai latar belakang masalah kriteria ketuntasan minimum (KKM) yang ditetapkan dari pihak sekolah yaitu 75diharapkan mencapai ketuntasan 75\% dari jumlah peserta didik yang mendapatkan nilai diatas atau sama dengan rata-rata KKM yaitu syarat pencapaian kelulusan yang dapat mewakilkan untuk setiap mata pelajaran (gambar konstruksi bangunan), dan diperoleh dari keseluruhan jumlah siswa diukur berdasarkan indikator aktivitas belajar siswa dengan rerata kelas mendapatkan kategori penilaian "AKTIF".

b. Hasil Belajar

- Rata-rata nilai hasil belajar siswa sesuai KKM minimal nilai 75 dengan ketercapaian sekurang-kurangnya $75 \%$ (ketuntasan klasikal) mengacu pada kriteria ketuntasan belajar minimum yang diterapkan SMK Negeri 1 Percut Sei Tuan.

* Sesuai latar belakang masalah kriteria ketuntasan minimum (KKM) yang ditetapkan dari pihak sekolah yaitu 75diharapkan mencapai ketuntasan 75\% dari jumlah peserta didik yang mendapatkan nilai diatas atau sama dengan rata-rata KKM yaitu syarat pencapaian kelulusan yang dapat mewakilkan untuk setiap mata pelajaran (gambar konstruksi bangunan), dan diperoleh dari keseluruhan jumlah siswa diukur berdasarkan setiap indikator disusun kedalam tes hasil belajar kompetensi kognitif dengan jumlah 25 soal pada siklus I, 24 soal pada siklus II dan tugas menggambar untuk kompetensi psikomotorik pada siklus I dan siklus II.

Hasil ketercapaian peningkatan aktivitas melalui penerapan media audio visual pada kelas XI Program Keahlian Teknik Gambar Bangunan SMK Negeri 1 Percut Sei Tuan, dapat dilihat pada tabel di bawah ini :

Tabel 1. Perbandingan Ketercapaian Aktivitas Belajar

\begin{tabular}{|c|c|c|c|}
\hline \multirow{2}{*}{ No } & Nama & \multicolumn{2}{|c|}{ Aktivitas Belajar } \\
\cline { 3 - 4 } & Responden & Siklus I & Siklus II \\
\hline 1 & Siswa 1 & 73 & 85 \\
\hline 2 & Siswa 2 & 83 & 95 \\
\hline 3 & Siswa 3 & 75 & 83 \\
\hline 4 & Siswa 4 & 60 & 80 \\
\hline 5 & Siswa 5 & 75 & 80 \\
\hline 6 & Siswa 6 & 80 & 93 \\
\hline 7 & Siswa 7 & 75 & 80 \\
\hline 8 & Siswa 8 & 83 & 85 \\
\hline 9 & Siswa 9 & 68 & 83 \\
\hline 10 & Siswa 10 & 78 & 85 \\
\hline 11 & Siswa 11 & 83 & 90 \\
\hline 12 & Siswa 12 & 70 & 80 \\
\hline 13 & Siswa 13 & 70 & 85 \\
\hline 14 & Siswa 14 & 68 & 80 \\
\hline 15 & Siswa 15 & 75 & 83 \\
\hline 16 & Siswa 16 & 70 & 80 \\
\hline 17 & Siswa 17 & 85 & 95 \\
\hline 18 & Siswa 18 & 75 & 85 \\
\hline 19 & Siswa 19 & 78 & 85 \\
\hline 20 & Siswa 20 & 75 & 83 \\
\hline 21 & Siswa 21 & 75 & 80 \\
\hline
\end{tabular}




\begin{tabular}{|c|c|c|c|}
\hline \multirow{2}{*}{ No } & \multirow{2}{*}{$\begin{array}{c}\text { Nama } \\
\text { Responden }\end{array}$} & \multicolumn{2}{|c|}{ Aktivitas Belajar } \\
\cline { 3 - 4 } & Siklus I & Siklus II \\
\hline 22 & Siswa 22 & 75 & 80 \\
\hline 23 & Siswa 23 & 78 & 83 \\
\hline 24 & Siswa 24 & 80 & 90 \\
\hline 25 & Siswa 25 & 80 & 85 \\
\hline 26 & Siswa 26 & 78 & 88 \\
\hline & Jumlah & $\mathbf{1 9 6 0}$ & $\mathbf{2 1 9 8}$ \\
\hline & $\begin{array}{c}\text { Rata-rata } \\
\text { Kelas (\%) }\end{array}$ & $\mathbf{7 5}$ & $\mathbf{8 5}$ \\
\hline & $\begin{array}{c}\text { Kenaikan } \\
\text { Presentase } \\
\text { (\%) }\end{array}$ & $\mathbf{9}$ & \\
\hline
\end{tabular}

Dengan demikian berdasarkan analisa tersebut dapat dinyatakan penerapan Media Audio Visual pada Kelas XI Program Keahlian Teknik Gambar Bangunan SMK Negeri 1 Percut Sei Tuan dapat meningkatkan aktivitas belajar siswa.

Hasil ketercapaian peningkatan hasil belajar melalui penerapan media audio visual pada Kelas XIProgram Keahlian Teknik Gambar Bangunan SMK Negeri 1 Percut Sei Tuan dapat dilihat pada tabel di bawah ini :

\section{Tabel 2. Perbandingan Ketercapaian Hasil Belajar siswa}

\begin{tabular}{|c|c|c|c|}
\hline \multirow{2}{*}{ No } & \multirow{2}{*}{ Nama } & \multicolumn{2}{|c|}{$\begin{array}{c}\text { Skor Perolehan } \\
\text { Hasil Belajar }\end{array}$} \\
\cline { 3 - 4 } & & Siklus I & Siklus II \\
\hline 1 & Siswa 1 & 76 & 85 \\
\hline 2 & Siswa 2 & 82 & 89 \\
\hline 3 & Siswa 3 & 73 & 81 \\
\hline 4 & Siswa 4 & 60 & 80 \\
\hline 5 & Siswa 5 & 70 & 81 \\
\hline 6 & Siswa 6 & 84 & 91 \\
\hline 7 & Siswa 7 & 76 & 81 \\
\hline 8 & Siswa 8 & 84 & 93 \\
\hline 9 & Siswa 9 & 60 & 78 \\
\hline 10 & Siswa 10 & 84 & 91 \\
\hline 11 & Siswa 11 & 86 & 95 \\
\hline
\end{tabular}

\begin{tabular}{|c|l|c|c|}
\hline \multirow{2}{*}{ No } & \multirow{2}{*}{ Nama } & \multicolumn{2}{|c|}{$\begin{array}{c}\text { Skor Perolehan } \\
\text { Hasil Belajar }\end{array}$} \\
\cline { 3 - 4 } & & Siklus I & Siklus II \\
\hline 12 & Siswa 12 & 76 & 81 \\
\hline 13 & Siswa 13 & 78 & 85 \\
\hline 14 & Siswa 14 & 80 & 85 \\
\hline 15 & Siswa 15 & 82 & 85 \\
\hline 16 & Siswa 16 & 64 & 83 \\
\hline 17 & Siswa 17 & 87 & 95 \\
\hline 18 & Siswa 18 & 76 & 81 \\
\hline 19 & Siswa 19 & 76 & 80 \\
\hline 20 & Siswa 20 & 78 & 83 \\
\hline 21 & Siswa 21 & 77 & 78 \\
\hline 22 & Siswa 22 & 73 & 78 \\
\hline 23 & Siswa 23 & 74 & 84 \\
\hline 24 & Siswa 24 & 86 & 91 \\
\hline 25 & Siswa 25 & 80 & 91 \\
\hline 26 & Siswa 26 & 76 & 85 \\
\hline & Jumlah & $\mathbf{2 0 0 0}$ & $\mathbf{2 2 1 2}$ \\
\hline & $\begin{array}{l}\text { Rata-rata } \\
\text { Kelas (\%) }\end{array}$ & $\mathbf{7 7}$ & $\mathbf{8 5}$ \\
\hline & $\begin{array}{l}\text { Kenaikan } \\
\text { Presentase } \\
\text { (\%) }\end{array}$ & $\mathbf{8}$ & \\
\hline & & & \\
\hline
\end{tabular}

Dengan demikian berdasarkan analisa tersebut dapat dinyatakan penerapan media audio visual pada mata pelajaran Gambar Konstruksi Bangunan siswa kelas XI Program Keahlian Teknik Gambar Bangunan SMK Negeri 1 Percut Sei Tuan dapat meningkatkan hasil belajar siswa.

\section{Kesimpulan, Implikasi dan Saran}

\subsection{Kesimpulan}

Berdasarkan hasil penelitian tindakan kelas (PTK) dapat disimpulkan sebagai berikut::

a. Penerapan media audio visualdapat meningkatkan aktivitas belajar siswa pada mata pelajaran Gambar Konstruksi Bangunan Siswa Kelas XI Program Keahlian Teknik Gambar Bangunan SMK Negeri 1 Percut Sei Tuan diterima dengan nilai rata-rata hasil pengamatan aktivitas belajar siswa pada siklus I dengan presentase nilai rata-rata kelas yaitu $75 \%$ dengan capaian $26,92 \%$ siswa tidak aktif 
$<75$ dan $73,08 \%$ siswa aktif $\geq 75$. Pada siklus II mengalami peningkatan dengan presentase nilai rata-rata kelas yaitu $85 \%$ meningkat dengan capaian $100 \%$ siswa aktif $\geq 75$.

a. Penerapan media audio visualdapat meningkatkan hasil belajar siswa pada mata pelajaran Gambar Konstruksi Bangunan Siswa Kelas XI Program Keahlian Teknik Gambar Bangunan SMK Negeri 1 Percut Sei Tuan diterima dengan nilai rata-rata hasil belajar siswa pada siklus I yaitu 76,91 dengan presentase ketuntasan siswa mencapai 73,08\%, dengan capaian target $26,92 \%$ nilai $<75$ dan $73,08 \%$ nilai $\geq 75$. Pada siklus II mengalami peningkatan dengan nilai ratarata hasil belajar siswa mencapai 85,08 dengan presentase ketuntasan siswa mencapai $100 \%$ atau 26 siswa dengan keterangan "Tuntas" yang mendapat nilai $\geq 75$.

\subsection{Saran}

Setelah melihat hasil penelitian, pembahasan dan kesimpulan maka peneliti memberikan saran sebagai berikut :

a. Bagi Kepala SMK Negeri 1 Percut Sei Tuan

Karena kegiatan ini sangat bermanfaat khususnya bagi sekolah, maka diharapkan mendukung pelaksanaan secara berkesinambungan sebagai referensi yang dapat digunakan oleh guru mata pelajaran lain.

b. Bagi Guru

Dalam kegiatan belajar mengajar guru diharapkan menjadikan media pembelajaran audio visual sebagai suatu alternatif dalam mata pelajaran Gambar Konstruksi Bangunan untuk meningkatkan aktivitas dan hasil belajar siswa. Guru diharapkan mampu menjadi fasilitator yang terus-menerus membimbing siswa dalam membangun sendiri pengetahuan dalam menyelesaikan permasalahan materi pembelajaran.

c. Bagi Siswa

Media pembelajaran audio visual ini dirancang untuk mengatasi kesulitan belajar siswa secara keseluruhan. Dengan demikian siswa diharapkan memiliki keaktifan belajar yang tinggi di dalam menerima suatu materi pelajaran dengan konsep pembelajaran media audio visual, hal ini akan berdampak positif bagi hasil belajar siswa itu sendiri.

d. Bagi peneliti

Selanjutnya diharapkan agar dapat memperhitungkan waktu yang dibutuhkan untuk setiap tahapan dan benar-benar dapat menyesuaikan alokasi waktu yang ada dengan rencana pembelajaran yang telah disesuaikan dengan RPP.

\section{Daftar Pustaka}

Arikunto, Suharsimi. (2012). Dasar-dasar Evaluasi Pendidikan. Jakarta: Bumi Aksara.

Arikunto, Suharsimi. (2013). Prosedur Penelitian Suatu Pendekatan Praktik. Jakarta: Rineka Cipta.

Arsyad, Azhar. (2014). Media Pembelejaran (Edisi Revisi). Jakarta: Rajawali Pers.

Darma, Rusli. Gambar konstruksi Bangunan Semester 4. Departemen Teknik Sipil dan Perencanaan; PPPPTK BMTI; 2003.

Djamarah, Bahri Syaiful. (2011). Psikologi Pendidikan. Jakarta: Rineka Cipta.

Djamarah, Bahri Syaiful. (2010). Strategi Belajar Mengajar. Jakarta: Rineka Cipta.

Indrawati. (2012). “Penggunaan Media Audio Visual Sebagai Upaya Meningkatkan Aktivitas Dan Hasil Belajar Materi Mengidentifikasi Ragam Lagu Daerah Pada Siswa Kelas V SD Negeri 04 Serang Petarukan Pemalang". Skripsi Fakultas Ilmu Pendidikan Universitas Negeri Semarang

Miarso, Yusufhadi. (2004). Menyemai Benih Teknologi Pendidikan. Jakarta: Prenada Media.

Miranda, Mufti. (2012). “Penggunaan Media Audio Visual Dalam Meningkatkan Prestasi Ilmu Pengetahuan Alam Kelas III B MI Sananul Ula Piyungan Bantul". Skripsi Fakultas Tarbiyah dan Keguruan UIN Sunan Kalijaga Yogyakarta.

Munadi, Yudhi. (2008). Media Pembelajaran : Sebuah Pendekatan Baru. Jakarta: Gaung Persada Pers.

Nana, Sudjana. (2004). Penilaian hasil proses belajar mengajar. Bandung: Remaja Rosdakarya.

Oloan, Elias Dame. (2013). “Upaya Meningkatkan Hasil Belajar Passing Atas Bola Voli Melalui Evaluasi Pembelajaran 
Menggunakan Media Audio Visual Pada Siswa Kelas X SMA Swasta Nasrani 1 Medan T.A 2012/2013". Skripsi Universitas Negeri Medan, Medan.

Rusman. (2012). Pembelajaran Berbasis Teknologi Informasi dan Komunikasi. Jakarta: Kencana Prenada Media Group. 